\title{
Pelatihan Administrasi PKK RW 06 Di Kelurahan Pedalangan Kecamatan Banyumanik Kota Semarang
}

\author{
Rita Andini, Sri Praptono \\ Fakultas Ekonomi Universitas Pandanaran, Indonesia \\ Email corresponding author: ritaandini007@ymail.com/sri_praptono@yahoo.com
}

\begin{abstract}
ABSTRAK
Gerakan PKK adalah Gerakan Nasional dalam pembangunan masyarakat yang tumbuh dari bawah, pengelolaannya dari, oleh dan untuk masyarakat menuju terwujudnya keluarga yang beriman dan bertaqwa kepada Tuhan Yang Maha Esa, berakhlak mulia dan berbudi luhur, sehat sejahtera, lahir dan batin. Mekanisme gerakan PKK terkoordinasi oleh Tim Penggerak PKK secara berjenjang mulai dari Tingkat Pusat, Provinsi, Kabupaten/Kota, Kecamatan hingga pada tingkat yang terkecil yaitu Kelurahan/Desa.Administrasi PKK adalah sistem pengelolaan yang berhubungan dengan kelembagaan PKK beserta dokumentasinya di setiap jenjang yang meliputi pencatatan, pendataan, pelaporan dan pengarsipan yang dilakukan secara manual maupun menggunakan Teknologi Informasi (TI).Administrasi PKK secara garis besar mencakup Administrasi Umum dan Administrasi Keuangan. Sejalan dengan perkembangan paradigma pembangunan kesehatan diharapkan telah mampu mewujudkan kesejahteraan masyarakat yang ditunjukkan dengan membaiknya berbagai indikator pembangunan Sumber Daya Manusia, seperti: meningkatnya derajat kesejahteraan dari status gizi masyarakat, meningkatnya kesetaraan gender, meningkatnya tumbuh kembang optimal, kesejahteraan dan perlindungan anak, terkendalinya jumlah dan laju pertumbuhan penduduk, serta menurunnya kesenjangan antar individu, antar kelompok masyarakat dan antar daerah dengan tetap lebih mengutamakan pada upaya pereventif, promotif serta pemberdayaan keluarga dan masyarakat dalam bidang kesehatan. Posyandu merupakan salah satu bentuk Upaya Kesehatan Bersumber Daya Masyarakat (UKBM) yang dikelola dan diselenggarakan dari, oleh, untuk dan bersama masyarakat dalam penyelenggaraan pembangunan kesehatan, guna memberdayakan masyarakat dan memberikan kemudahan kepada masyarakat dalam memperoleh pelayanan kesehatan dasar, utamanya untuk mempercepat penurunan angka kematian ibu dan bayi. Penulis mencoba mengangkat persoalan ini dan memberikan pelatihan administrasi Kelompok PKK RW guna mendukung tertib administrasi Tim Penggerak PKK tingkat Kelurahan. Data yang dihasilkan berupa rekapitulasi Data Keluarga, Catatan Data dan Kegiatan Warga, Catatan Ibu Hamil, Melahirkan, Nifas, Ibu Meninggal, Kelahiran Bayi, Bayi Meninggal dan Kematian Balita. Yang diperoleh dari Kelompok PKK RT dan Dasawisma.Metode yang digunakan dalam pelatihan ini terdiri dari metode ceramah, diskusi, pelatihan (workshop). Selanjutnya metode yang digunakan adalah demonstrasi yaitu implementasi pengisian formulir administrasi sehingga data yang dimiliki lengkap, akurat, dan jelas.
\end{abstract}

Kata Kunci : PKK, Administrasi PKK, Kelompok PKK RW/RW, Dasawisma

\section{PENDAHULUAN}

Program pengabdian kepada masyarakat merupakan salah satu program yang wajib dilaksanakan, baik oleh dosen maupun oleh mahasiswa, dengan berlandaskan pada prinsip-prinsip: kompetensi akademik, jiwa kewirausahaan (entrepreneurship), dan profesional, sehingga dapat menghasilkan program pengabdian kepada masyarakat yang bermutu, relevan, dan sinergis dalam meningkatkan pemberdayaan masyarakat. Bentuk pengabdian kepada masyarakat dilakukan Tim Pengabdian Kepada Masyarakat secara interdisipliner, institusional, dan kemitraan sebagai salah bentuk kegiatan Tridharma Perguruan Tinggi. Seiring dinamika masyarakat, pemerintah daerah, pemerintah pusat maupun dunia global, maka program Pengabdian Kepada Masyarakat di Universitas Pandanaran Semarang diarahkan pada pola Tematik berbasis pemberdayaan masyarakat. Salah satu daerah yang menjadi perhatian utama dalam kegiatan Pengabdian Kepada Masyarakat Universitas Pandanaran Semarang kali ini adalah Kecamatan Banyumanik Kota Semarang.

Program Pengabdian Kepada Masyarakat dijalankan dengan kegiatan yangmemiliki relevansi dengan Pembangunan Nasional. Pembangunan Nasional merupakan segala usaha yang dilakukan oleh semua komponen bangsa dalam rangka mencapai tujuan bermasyarakat, berbangsa dan bernegara. Pembangunan akan berhasil dengan efektif apabila tersedia fasilitas, kemudahankemudahan dan sistem pelayanan yang disediakan pemerintah dan adanya partisipasi aktif seluruh 
komponen masyarakat. Keluarga sebagai unit terkecil dalam masyarakat mempunyai peranan yang besar dalam proses pembangunan, karena kondisi suatu keluarga dapat dijadikan sebagai tolak ukur terhadap kesejahteraan masyarakat pada umumnya. Untuk dapat membina keluarga secara langsung dan menjangkau sasaran sebanyak mungkin, dibentuk Gerakan Pemberdayaan dan Kesejahteraan Keluarga (PKK). Gerakan PKK adalah Gerakan Nasional dalam pembangunan masyarakat yang tumbuh dari bawah, pengelolaannya dari, oleh dan untuk masyarakat menuju terwujudnya keluarga yang beriman dan bertaqwa kepada Tuhan Yang Maha Esa, berakhlak mulia dan berbudi luhur, sehat sejahtera, lahir dan batin. Gerakan PKK dituntut untuk menumbuh kembangkan sikap dan perilaku, kemandirian, pribadi, keluarga dan masyarakat agar tidak salah dalam menghadapi berbagai perubahan yang terjadi dewasa ini. Mekanisme gerakan PKK terkoordinasi oleh Tim Penggerak PKK secara berjenjang mulai dari Tingkat Pusat, Provinsi, Kabupaten/Kota, Kecamatan hingga pada tingkat yang terkecil yaitu Kelurahan/Desa.

Dalam pengelolaan PKK tentu diperlukan kelengkapan administrasi baik berupa administrasi umum maupun administrasi keuangan. Pengumpulan data administrasi umum mengenai datakeluarga, ibu hamil, melahirkan, nifas, ibumeninggal, kelahiran bayi, bayi meninggal dankematian balita perlu dilakukan secara langsung kepada warga. Maka dari itu, untuk mendekatkan jangkauan pembinaan kepada keluarga-keluarga dibentuk kelompok-kelompok berdasarkan kewilayahan yaitu : PKK Dusun/Lingkungan, RW, RT sampai dengan kelompok Dasawisma. Memperhatikan pentingnya administrasi pada kelompok PKK untuk mendukung Tim Penggerak PKK, maka Tim Pengabdian Kepada Masyarakat Universitas Pandanaran Semarang ingin berperan aktif untuk mengembangkansumberdaya warga sekitar dengan mengusung tema : "Pelatihan Administrasi PKK RW.06 Di Kelurahan Pedalangan Kecamatan Banyumanik Kota Semarang".

\section{METODE PELAKSANAAN}

\section{Waktu dan Tempat}

Penyuluhan dan pelatihan PKK dilaksanakan di Aula Kelurahan Pedalangan Kecamatan Banyumanik Kota Semarang pada tanggal 24 Juli 2020.

\section{Metode}

Kegiatan-kegiatan yang dilakukan berdasarkan solusi yang ditawarkan

1) Meningkatkan pemahaman mengenai tata cara pengisian data pada buku administrasi Kelompok PKK secara baik dan benar.

2) Mendorong tertib administrasi Kelompok PKK RW, Kelompok PKK RT dan Dasawiswa.

3) Memberikan solusi pemenuhan kebutuhan buku administrasi Kelompok PKK.

4) Meningkatkan niat, semangat, dan kesadaran Ibu-ibu anggota Kelompok PKK untuk berperan aktif dalam organisasi Gerakan PKK.

\section{Kontribusi Partisipasi Mitra}

Partisipasi mitra dalam pelaksanaan pelatihan administrasi PKK adalah:

1. Mengumpulkan seluruh Kelompok PKK RW, maka diikutsertakan pula Kelompok PKK RT dan Dasawisma yang berada pada garis koordinasi di bawahnya di Kelurahan Pedalangan Kecamatan Banyumanik.

2. Menyediakan tempat pelaksanaan penyuluhan dan pelatihan.

3. Menyediakan bahan dan alat pendukung. 


\section{HASIL KEGIATAN}

Kegiatan pelatihan administrasi kepada kelompok PKK telah dilaksanakan dengan yang ada dalam kelompok Dasawisma dan Kelompok PKK RT dan PKK RW di Kelurahan Pedalangan Kecamatan Banyumanik. Kegiatan pelatihan ini berlangsung pada tanggal 24 Juli 2020 yang bertempat di Aula Kelurahan Pedalangan Kecamatan Banyumanik yang dihadiri oleh sebanyak 28 orang peserta. Adapun jenis kegiatan yang disajikan dalam 4 bentuk yaitu pertama adalah penyuluhan Meningkatkan pemahaman mengenai tata cara pengisian data pada buku administrasi Kelompok PKK secara baik dan benar, Mendorong tertib administrasi Kelompok PKK RW, Kelompok PKK RT dan Dasawiswa, Memberikan solusi pemenuhan kebutuhan buku administrasi Kelompok PKK. Kemudian penyuluhan Meningkatkan niat, semangat, dan kesadaran Ibu-ibu anggota Kelompok PKK untuk berperan aktif dalam organisasi Gerakan PKK.
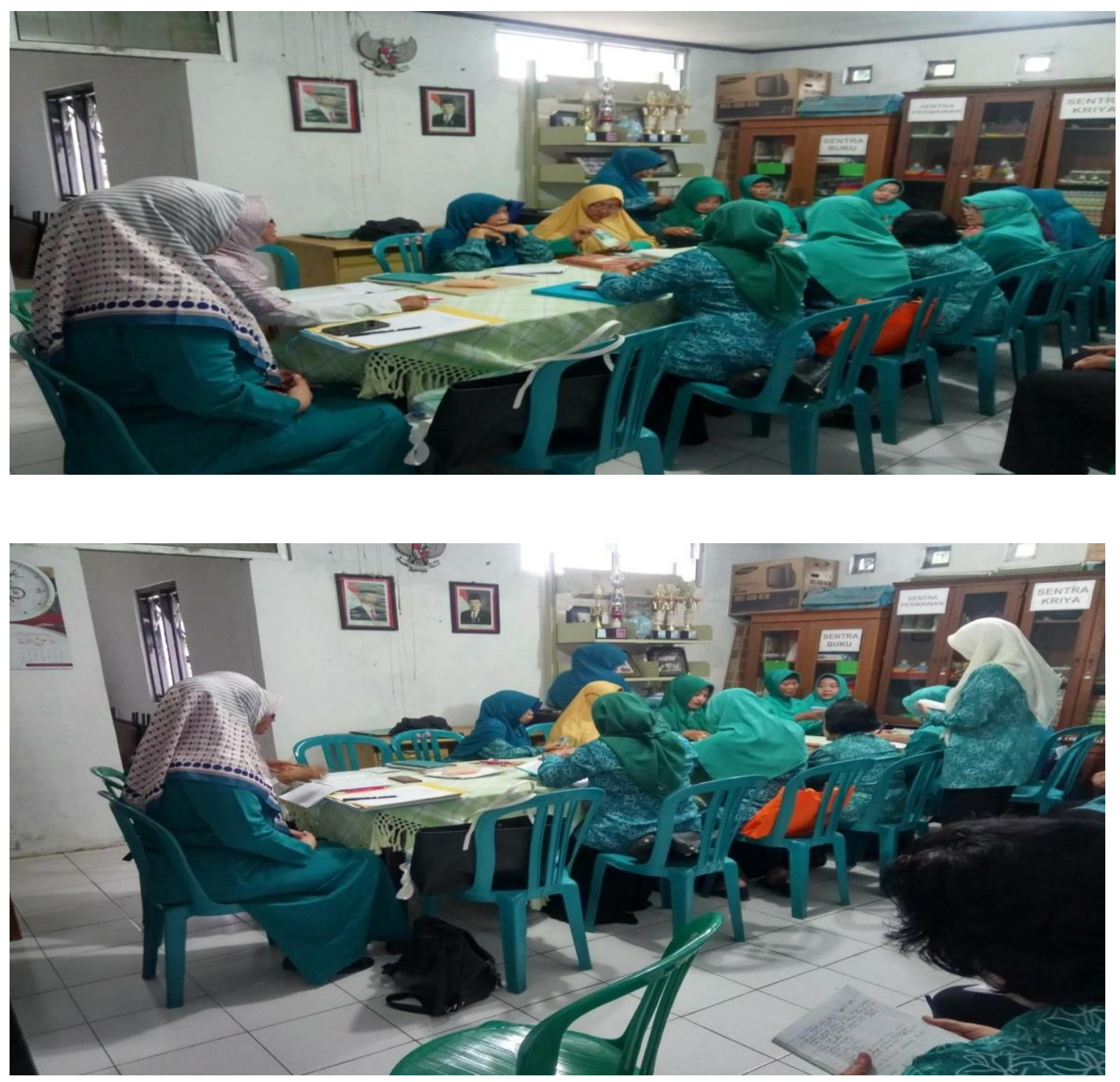

Gambar 1. Pemberian Materi oleh Tim Pengabdian Kepada Masyarakat 


\section{KESIMPULAN}

Kegiatan Program Pengabdian Kepada Masyarakatyang dilaksanakan oleh Universitas Pandanaran dengan Kegiatan Pelatihan Administrasi PKK berjalan dengan baik dan lancar. Upaya peningkatan motivasi dan pemahaman administrasiKelompok PKK RW.06 di Kelurahan Pedalangan Kecamatan BanyumanikKota Semarang membuahkan hasil meskipun tidak dapat dipastikan seberapa tinggi hasil yang diperoleh. Para peserta yang hadir mengikuti pelatihan termotivasi untuk bersemangat aktif dalam segala bentuk kegiatan PKK. Dengan semangat yang dimiliki selama kegiatan, peserta pada akhirnya mampu mengimbangi dan menyerap informasi panduan pengisian rekapitulasi data admistrasi. Namun kegiatan ini juga memiliki keterbatasan. Keterbatasan yang pertama yaitu waktu pelatihan dan fasilitas peralatan yang minim. Permasalahan pemenuhan kekurangan buku administrasi terselesaikan meskipun harus menggunakan uang yang dihimpun dari iuran para anggota. Keterbatasan yang lain yaitu kurangnya antusias para peserta undangan sehingga jumlah yang hadir kurang dari yang diharapkan.

\section{UCAPAN TERIMAKASIH}

Penulis mengucapkan terima kasih kepada Lembaga Penelitian dan Pengabdian Kepada Masyarakat Universitas Pandanaran dan Fakultas Ekonomi yang telah membiayai pengabdian ini pada Tahun Anggaran 2020. Penulis juga mengucapkan terimakasih kepada kelompok wanita Dasawisma dan Ibu Ibu PKK RT dan PKK RW Kecamatan Banyumanik atas partisipasinya dalam kegiatan pengabdian ini.

\section{DAFTAR PUSTAKA}

Arikunto, Suharsimi, 2002. Prosedur Penelitian Suatu Pendekatan Praktek. Jakarta. PT. Rineka Cipta.

Basuki, Sulistyo. 2006. Metode Peneletian Jakarta. Wedatama Widya Sastra

Mindarti, L.I dan N. Fauziah, 2016. Pemberdayaan Kader PKK untuk Membantu Pendataan Kepemilikan Akta Kelahiran. Studi Pada Pelayanan Kependudukan Kelurahan Kidul Dalem, Kecamatan Klojen, Kota Malang, Populasi. Vol. 24 No.1 h. 26-35

Notoatmodjo, S. 2005. Metodologi Penelitian Kesehatan Jakarta Rineka Cipta

Riduwan, 2005. Skala Pengukuran Variabel-Variabel Penelitian. Bandung Alfabeta

Tim Penggerak Pusat PKK 2015. Pemberdayaan dan Kesejahteraan Keluarga Rumusan Hasil Rakernas VIII PKK Tahun 2015. Jakarta Tim Penggerak Pusat 